\title{
KŁOPOTLIWE INSTYTUCJE PRAWA HISZPAŃSKIEGO I POLSKIEGO - ANALIZA PORÓWNAWCZA I TERMINOLOGICZNA
}

\author{
Anna Magdalena DORABIALSKA, mgr \\ Instytut Prawa Międzynarodowego, Wydział Prawa i Administracji, \\ Uniwersytet Warszawski, \\ ul. Krakowskie Przedmieście 1, 00-927 Warszawa \\ anna.dorabialska@gmail.com
}

\begin{abstract}
Abstrakt: Artykuł powstał na podstawie analizy prawnoporównawczej i terminologicznej wybranych przykładów $\mathrm{z}$ zakresu prawa polskiego i hiszpańskiego. Celem autorki jest zastosowanie metody komparatystycznej do rozważań dotyczących ekwiwalentów polskich oraz hiszpańskich terminów i instytucji prawnych. Uwagi wstępne dotycza miejsca badanych porządków prawnych w klasyfikacji systemów występujących na świecie. Główny wywód składa się z trzech części. Pierwsza dotyczy nazewnictwa powiązań osób fizycznych oraz prawnych z określonym obszarem prawnym. Druga odnosi się do prawa spadkowego i skupia się na teoretycznoprawnym ukształtowaniu instytucji zachowku w obu analizowanych systemach. W ostatniej części zaś autorka koncentruje się na strukturze organów spółek kapitałowych zestawiając model organizacyjny hiszpańskich i polskich spółek akcyjnych oraz spółek z ograniczoną odpowiedzialnością, nawiązując do terminologii wprowadzonej przez prawo Unii Europejskiej oraz podejmując się analizy niektórych ekwiwalentów funkcjonujących w obrocie gospodarczym między Hiszpanią a Polską.
\end{abstract}

\section{PROBLEMATIC INSTITUTIONS OF SPANISH AND POLISH LEGAL SYSTEMS - A COMPARATIVE AND TERMINOLOGICAL ANALYSIS}

\begin{abstract}
The article is based on the comparative and terminological analysis of selected examples from the Spanish and the Polish law. The author's objective is to apply the legal comparative methods to the considerations about equivalents for Polish and Spanish terms and legal concepts. The introduction regards the placement of analized jurisdictions in the classification of legal systems in the world. The main argumentation consists of three parts. The first one refers to the nomenclature of connections between natural or legal persons and a determined legal system. The second section concerns the Inheritance Law and focuses on the legal theory of the concept of the reserved portion in both analized systems. In the last part the author describes the organization of company bodies contrasting the models of Polish and Spanish limited liability companies and joint-stock companies, with reference to the notions introduced in the EU-Law.
\end{abstract}




\section{Wprowadzenie}

Niniejszy artykuł referat stanowi analizę prawnoporównawczą polskiego i hiszpańskiego porządku prawnego dokonaną pod kątem pracy tłumacza. Celem autorki nie jest definitywne wskazanie najlepszych ekwiwalentów dla omawianych instytucji, ale podkreślenie aspektów teoretycznoprawnych o szczególnym znaczeniu dla doboru odpowiedników językowych. Artykuł dotyczy wybranych kwestii z zakresu prawa prywatnego.

\section{Charakter systemów prawa polskiego i hiszpańskiego}

Dokonanie zestawienia polskich i hiszpańskich instytucji prawnych nie jest zadaniem wyjątkowo skomplikowanym. Oba systemy wpisują się znakomicie w tradycję kontynentalną, bazującą na instytucjach wywodzących się z prawa rzymskiego. Jednak wewnątrz kontynentalnego systemu prawa, nazywanego też grupą romańsko-germańską, wyróżnia się dwie podstawowe rodziny prawa: germańską, w której główna rolę odgrywa prawo niemieckie oraz romańską, w której dominującą pozycję zyskało prawo francuskie. Prawo hiszpańskie jest modelowym przykładem systemu zakorzenionego w prawie francuskim, wystarczy wspomnieć, ze obowiązujący do dziś podstawowy kodeks w dziedzinie prawa prywatnego - Kodeks cywilny z 1889 r. ${ }^{1}$ został oparty na francuskim Code civile (tzw. kodeksie Napoleona) z 1806 r.

Prawo polskie natomiast, choć $w$ największym stopniu wywodzące się z niemieckiej myśli prawniczej i należące do rodziny germańskiej, zawiera również wpływy francuskie, zwłaszcza na gruncie prawa cywilnego (przeniesienie własności, ustawowy ustrój wspólności małżeńskiej). Ułatwieniem dla tłumacza języka hiszpańskiego jest fakt, że ogólna klasyfikacja gałęzi i instytucji prawnych w obu językach co do zasady pokrywa się. Wyzwanie stanowi, natomiast, zupełnie częstokroć odmienny charakter instytucji, które wydawałyby się odpowiednikami, z jednej strony, i ekwiwalentny charakter różnych na pierwszy rzut oka pojęć, z drugiej.

\section{Pojęcia opisujące powiązanie jednostki z określonym obszarem prawnym}

Powiązanie podmiotu $\mathrm{z}$ pewnym obszarem prawnym jest niezbędne by ustalić właściwość organów danego państwa czy też określonego systemu prawa. Kryterium powiązania może być np. obywatelstwo, miejsce zamieszkania, siedziba, miejsce zwykłego pobytu. Niektóre określenia odnoszą się jedynie do osób fizycznych, inne wyłącznie do osób prawnych lub do obu tych rodzajów uczestników obrotu prawnego. Często jednak pojęcia języka wyjściowego odnoszące się zarówno do osób fizycznych, jak i prawnych mają w języku docelowym odmienne ekwiwalenty. Rozróżnienie pomiędzy terminami odnoszącymi się do osób fizycznych a terminami związanymi $\mathrm{z}$ osobami prawnymi jest właściwe przede wszystkim dla polskiego języka prawnego i prawniczego.

Drugą cechą porządkującą omawiane terminy jest charakter powiązania, do jakiego się odnoszą. Większość z nich opisuje powiązanie o charakterze terytorialnym, innymi słowy wskazuje na to, że dana osoba posiada na danym terytorium określone centrum interesów życiowych lub gospodarczych (np. miejsce zamieszkania, stałego

\footnotetext{
${ }^{1}$ Código civil (Gazeta de Madrid núm. 206 a 208, de 25, 26 y 27 de julio de 1889 ze zm.)
} 
pobytu, siedzibę itd.). Istnieją również terminy wskazujące na powiązanie jednostki $\mathrm{z}$ terytorium polegające na określeniu przynależności do pewnej grupy związanej z tym terytorium za pomocą umownej instytucji prawnej, takiej jak np. obywatelstwo, które mogą, lecz nie muszą, wiązać się z posiadaniem wspomnianego centrum interesów życiowych lub gospodarczych na tym terytorium, determinują jednak, w większym lub mniejszym stopniu, podległość jednostki wyznaczonemu w ten sposób systemowi prawa. Trzecim, istotnym czynnikiem wpływającym na rozróżnienie tych pojęć jest ich określona obecność w aktach prawa UE oraz prawa krajowego. Warto wspomnieć również, że niektóre $\mathrm{z}$ nich mogą posiadać różne znaczenia, w zależności od gałęzi prawa, do której się odnoszą (residencia habitual: stały pobyt - prawo prywatne międzynarodowe, residencia fiscal - rezydencja podatkowa - prawo publiczne (finansowe).

Jednym z podstawowych kryteriów jest obywatelstwo. Zgodnie z panującą na gruncie prawa międzynarodowego zasadą równości i suwerenności podmiotów tego prawa, każde państwo samodzielnie określa zasady jego nabywania. W języku hiszpańskim pojęciu obywatelstwa odpowiada termin nacionalidad. Inaczej jednak niż w języku polskim odnosić się on może zarówno do osób fizycznych, jak i osób prawnych (np. sociedad xxx de nacionalidad española). Określenie takie nawiązuje do art. 9.11 hiszpańskiego kodeksu cywilnego wskazującego statut personalny osób prawnych. Zdaniem przedstawicieli hiszpańskiej nauki prawa pojęcie „narodowości” spółki należy rozumieć jako przynależność podmiotu do pewnego porządku prawnego, który to porządek sam uznaje się za właściwy do regulowania spraw spółki ${ }^{2}$. Nie istnieje bowiem jednolite kryterium przyporządkowania osoby prawnej do określonego systemu prawnego. Przykładowo w porządkach prawnych niektórych państw zakłada się, że podległe ich systemowi prawa są podmioty założone na ich terytorium, niezależnie od tego, gdzie znajduje się główny ośrodek zarządu, czy też ich główne przedsiębiorstwo (tzw. teoria inkorporacji), inne zaś uznają za „swoje” jedynie te spółki, które na ich terytorium mają swoją siedzibę, rozumianą jako spełnienie co najmniej jednego z powyższych kryteriów (tzw. teoria siedziby). Owa wpisana do hiszpańskiego kodeksu cywilnego „narodowość” osoby prawnej to nic innego, jak jej przynależność do określonego systemu prawnego, podległość określonemu prawu ${ }^{3}$. Stąd najbardziej prawidłowym z punktu widzenia nauki i praktyki prawa jest tłumaczenie wyrażenia sociedad de nacionalidad española jako spótka prawa hiszpańskiego.

Podobnie jak nacionalidad hiszpańskie pojęcie domicilio można tłumaczyć na język polski dwojako. W odniesieniu do osób fizycznych termin ten odpowiada wyrażeniu miejsce zamieszkania, w stosunku zaś do osób prawnych pojęciu siedziby. Innym hiszpańskim odpowiednikiem polskiego terminu siedziba, odnoszącym się już wyłącznie do osób prawnych i innych jednostek organizacyjnych jest sede. Jeżeli w tekście hiszpańskim pojęcie domicilio odnosi się do każdego typu podmiotów prawa, powinno być tłumaczone w sposób rozszerzony, tak, jak czyni się to w tekstach polskich aktów prawnych ${ }^{4}$, czyli ,miejsce zamieszkania lub siedziba”. Jedyny wyjątek stanowi

\footnotetext{
${ }^{2}$ Calvo Caravaca, i Carrascosa González 2009, 404.

${ }^{3}$ Ibidem, s. 403.

${ }^{4}$ Np. art. 241 pkt 1 ustawy z dnia 28 lutego 2003 r. - Prawo upadłościowe i naprawcze; art. 3 ust. 1 pkt 2 ustawy z dnia 6 grudnia 1996 r. o zastawie rejestrowym i rejestrze zastawów.
} 
tekst rozporządzenia Rozporządzenie Rady (WE) nr 44/2001 w sprawie jurysdykcji i uznawania orzeczeń sądowych oraz ich wykonywania $w$ sprawach cywilnych i handlowych (,Bruksela I”) oraz teksty odnoszące się do tego aktu prawnego czy też go opisujące. W rozporządzeniu „Bruksela I” pojęcie miejsca zamieszkania (domicilio) odnosi się zarówno do osób fizycznych, jak i do podmiotów zbiorowych, w stosunku do których jego znaczenie zostało zdefiniowane w art. 60 tegoż aktu.

Pojęciem o zbliżonym znaczeniu do miejsca zamieszkania lub siedziby jest miejsce zwykłego pobytu, którego hiszpański odpowiednik stanowi termin residencia habitual. Zgodnie z doktryną prawa kolizyjnego zarówno w Polsce jak i w Hiszpanii pojęcia miejsca zamieszkania i miejsca zwykłego różnią się od siebie stopniem intensywności faktycznych powiązań podmiotu $\mathrm{z}$ danym terytorium. W obu przypadkach chodzi o centrum interesów życiowych, miejsce zamieszkania jednak zakłada równoczesny zamiar osiedlenia się na danym terytorium, podczas gdy miejsce zwykłego pobytu określane jest za pomocą kryteriów czysto faktycznych. Właśnie kategoria zwykłego pobytu występuje najczęściej w tekstach prawnych pochodzenia unijnego lub międzynarodowego. Wystarczy wspomnieć Rozporządzenie Parlamentu Europejskiego i Rady (WE) nr 593/2008 w sprawie prawa właściwego dla zobowiązań umownych (,Rzym I”) czy też o konwencjach haskich, (np. Konwencji dotyczącej kolizji praw w przedmiocie formy rozrządzeń testamentowych). Warto zwrócić uwagę na to, że podczas gdy w języku hiszpańskim od lat utrzymuje się tutaj jeden termin - residencia habitual, w polskim języku prawniczym funkcjonowały trzy równorzędne ekwiwalenty: miejsce statego pobytu, miejsce zwyktego pobytu oraz miejsce zwyczajnego pobytu ${ }^{5}$, przy czym wiele tłumaczeń konwencji haskich zawiera wersję miejsce statego pobytu, a teksty prawa unijnego miejsce zwyktego pobytu. W związku z ustaleniem się nazwy tej instytucji w tekstach prawa UE, należy się spodziewać, że wersja miejsce zwyktego pobytu będzie z czasem najczęściej stosowaną nazwą tego łącznika.

Należy podkreślić, że w języku hiszpańskim termin residencia może mieć szersze znaczenie niż odnoszące się w zasadzie wyłącznie do kolizji praw polskie miejsce zwykłego pobytu. Jeżeli tekst wyraźnie nie dotyczy stosunków prawnych z elementem międzynarodowym, hiszpańskie residente de może oznaczać dokładnie to samo co domiciliado en, czyli wskazywać na okoliczność zamieszkania na pewnym terytorium. W języku hiszpańskim, inaczej niż w polskim istnieje też możliwość nazwania w ten sam sposób faktu zamieszkania w określonym miejscu oraz bycia rezydentem w znaczeniu przyjmowanym przez ustawodawstwo podatkowe (residencia fiscal). W języku polskim odnośnie do stosunków prawa finansowego używa się terminu rezydencja podatkowa.

Terminologia hiszpańska jest bogatsza co do określeń zamieszkania podmiotu w danym państwie, regionie czy też miejscowości. Poza opisanymi powyżej pojęciami domicilio oraz residencia (habitual) często spotyka się również określenie vecino de

\footnotetext{
${ }^{5}$ Zob. np. Pazdan 2008, 54 i n.

${ }^{6} \mathrm{~Np}$. Konwencja o prawie właściwym dla zobowiązań alimentacyjnych, sporządzona w Hadze 2 października 1973 r. (Dz. U. z 2000 r. Nr 39, poz. 444 i 445); Konwencja o właściwości organów i prawie właściwym w zakresie ochrony małoletnich sporządzona w Hadze 5 października 1961 r. (Dz. U. z 1995 r. Nr 108, poz. 528 ze zm.); Konwencja o uznawaniu rozwodów i separacji sporządzona w Hadze 1 czerwca 1970 r. (Dz. U. z 2001 r. Nr 53, poz. 561 i 562). Warto zwrócić uwagę, ze wersja miejsce zwykłego pobytu" znalazła się natomiast w tłumaczeniu Konwencji dotyczącej kolizji praw w przedmiocie formy rozrządzeń testamentowych sporządzonej w Hadze 5 października 1961 r. (Dz. U. Nr 34, poz. 285).
} 
odnoszące się hiszpańskiej instytucji prawnej, jaką jest vecindad. Interpretacja zwrotu vecino de może okazać się dla tłumacza niezwykle problematyczna. Hiszpański język prawny i prawniczy odnosi bowiem ten termin do dwóch zupełnie różnych instytucji prawnych. Vecindad administrativa oznaczająca urzędowe przypisanie podmiotu do miejscowości, w której zamieszkuje (empadronamiento), ma znaczenie w świetle przepisów prawa administracyjnego i odpowiada polskiemu zameldowaniu, dlatego może być tłumaczona jako „zameldowany” lub „zamieszkały”. Poza odpowiednikiem polskiego zameldowania istnieje jednak również pojęcie vecindad civil, przewidziane dla skutków w zakresie prawa cywilnego i mające związek z niejednolitością systemu prawa cywilnego występującą na terytorium Hiszpanii.

Część regionów, w których obowiązywało tradycyjne odrębne prawo cywilne posiada swoje własne kompilacje, przede wszystkim w zakresie prawa spadkowego, majątkowego małżeńskiego oraz niektórych aspektów prawa rzeczowego. Na mocy art. 149 ust. 1 pkt 6 i pkt 8 Konstytucji hiszpańskiej ${ }^{7}$ prawa regionalne (derechos forales, derechos especiales) nie mogą regulować zagadnień prawa handlowego, podstawowych zasad zobowiązań umownych, formy zawarcia małżeństwa, organizacji rejestrów oraz prawa kolizyjnego. Własne zbiory norm prawa cywilnego, mające pierwszeństwo przed przepisami Kodeksu zostały utrzymane bądź skodyfikowane w Kraju Basków (Vizcaya, Álava i Guipúzcoa), Katalonii, Galicji, Aragonii, Regionie Nawarry oraz na Balearach. Vecindad civil jest kryterium wprowadzonym przez art. 14 ust. 1 Kodeksu cywilnego wyznaczającym podległość podmiotu określonemu specjalnemu prawu regionalnemu lub prawu powszechnemu (derecho común), zapisanemu w Kodeksie oraz ustawach go rozwijających. Kryterium to nie odnosi się bezpośrednio do faktu zamieszkania na danym terytorium, a jest nabywane, podobnie jak obywatelstwo po rodzicach, wraz $\mathrm{z}$ urodzeniem. Jest więc łącznikiem o charakterze personalnym, nie zaś terytorialnym. W pewnych przypadkach określoną vecindad civil można nabyć wskutek zamieszkania na terytorium, na którym obowiązuje specjalne prawo regionalne ${ }^{8}$, zmiana miejsca zamieszkania nie wpływa jednak na podległość lokalnemu systemowi prawa cywilnego. Podległość określonemu systemowi prawa regionalnego może więc, lecz nie musi, oznaczać zamieszkania w tymże regionie. Podobna instytucja funkcjonowała w Polsce w prawie międzydzielnicowym XX-lecia międzywojennego ${ }^{9}$ pod nazwą przynależności dzielnicowej. Ten zapomniany ekwiwalent wydaje się pomocny w tłumaczeniu tekstów hiszpańskich odnoszących się do vecindad civil. W tym kontekście możemy mówić o przynależności regionalnej lub podległości prawu (np. katalońskiemu).

Terminy określające związek osoby z danym obszarem występują powszechnie w umowach cywilnoprawnych oraz $\mathrm{w}$ tekstach prawniczych odnoszących się do prawa UE. Nie zawsze przy tym stosowane są konsekwentnie. Tak też tylko znajomość

\footnotetext{
${ }^{7}$ Constitución española de 27 de diciembre de 1978 (BOE de 29 de diciembre de 1978).

${ }^{8}$ Zgodnie z art. 14 ust. 5 kodeksu cywilnego po dwóch latach nieprzerwanego zamieszkania na terytorium, na którym obowiązuje prawo specjalne można wnieść o nabycie vecindad civil odpowiadającej miejscu zamieszkania, natomiast po 10 latach nabywa się ją z mocy prawa pod warunkiem jednak, że nie została zgłoszona chęć pozostania przy przynależności dotychczasowej.

${ }^{9}$ Ustawa z 2 sierpnia 1926 o prawie właściwem dla stosunków prywatnych wewnętrznych (Dz. U. z 1926 r. $\mathrm{Nr} 101$, poz. 580).
} 
prawnych niuansów ich rozumienia i stosowania może uchronić tłumacza przed interpretacją tekstu niezgodną z zamierzeniami autora.

\section{Zachowek w polskim i hiszpańskim systemie prawnym}

Zarówno polski, jak i hiszpański porządek prawny chronią najbliższą rodzinę spadkodawcy przed całkowitym pozbawieniem udziału w schedzie spadkowej. W przeciwieństwie do systemów anglosaskich spadkodawca polski czy hiszpański nie może zupełnie dowolnie rozporządzać swoim majątkiem. W nauce prawa instytucja zabezpieczająca interesy najbliższej rodziny nazywana jest zachowkiem.

Ochrona najbliższych krewnych spadkodawcy może jednak zostać zapewniona w dwojaki sposób. Teoria prawa rozróżnia tutaj dwa systemy: zachowku i rezerwy ${ }^{10}$. System zachowku polega na zapewnieniu osobom należącym do najbliższych krewnych spadkodawcy roszczenia o równowartość ustawowo określonej części spadku, jaka przypadałaby im, gdyby nastąpiło dziedziczenie beztestamentowe. System rezerwy natomiast zakłada umowny podział schedy spadkowej na trzy części. Jedną z nich testujący może rozporządzać całkowicie dowolnie, druga przeznaczona jest określonemu kręgowi spadkobierców (w pierwszej kolejności zstępnym) w ściśle określonych proporcjach. Trzecia zaś część ma charakter pośredni. Co prawda nie podlega zupełnie swobodnej dyspozycji testatora, gdyż przeznaczona jest dla tych samych osób, którym przypada część pierwsza. Spadkodawca może jednak swobodnie dysponować tą częścią przypisując ją dowolnym zstępnym (np. wnukom, mimo że dzieci są zdolne do dziedziczenia) w dowolnych proporcjach. Jeżeli jednak spadkodawca nie skorzysta z takiego prawa, część ta podlega równemu podziałowi pomiędzy bezpośrednich zstępnych, czyli reżimowi zachowkowemu. W systemie rezerwy spadkobiercy konieczni (legitimarios) są autentycznymi spadkobiercami, czyli następcami prawnymi pod tytułem uniwersalnym, uprawnionym do zachowku w modelu zachowkowym przysługuje zaś jedynie roszczenie majątkowego do ustanowionego spadkobiercy. Trudności w tłumaczeniu wyrażenia en concepto (en calidad) de mejora zawieranego w aktach ostatniej woli wiążą się właśnie $\mathrm{z}$ tym całkowicie innym postrzeganiem zachowku przez teorię prawa. O ile jednak tłumacz tekstów użytkowych (inaczej niż tłumacz tekstu naukowego czy opinii o charakterze porównawczoprawnym) może skorzystać z ekwiwalentu funkcjonalnego, jakim jest zachowek, nie będzie w stanie znaleźć prostego odpowiednika pojęcia mejora.

Można proponować różne warianty tłumaczenia, np. zapis naddziałowy, zachowek rozporzadzalny, zapis zachowkowy. Każdy z nich jednak zawiera wady z punktu widzenia prawnego. Tłumacząc termin mejora jako zapis narażamy się na niebezpieczeństwo zatarcia podstawowej różnicy między pojęciami spadkobiercy i zapisobiercy. Spadkobierca (heredero) bowiem to osoba, które dziedziczy pod tytułem uniwersalnym, czyli przejmuje ogół praw i obowiązków spoczywających na zmarłym. Zapisobierca zaś (legatario) to osoba powołana do dziedziczenia konkretnego dobra, np. domu, samochodu itp. Mejora zaś może być ustanowiona zarówno w drodze ustanowienia spadkobierca jak i za pomoca, a nawet w drodze darowizny dokonanej za życia. Pojęcie mejora nie będzie nigdy jednak odnosić się do czynności prawnej (ustanowieniem

\footnotetext{
${ }^{10}$ Sójka-Zielińska 2003, 278-279.
} 
spadkobiercy, legatem itp.), ale do koncepcji służącej do obliczania zachowku należnego zstępnym spadkodawcy ${ }^{11}$. Z drugiej strony zwięzłe ekwiwalenty, takie jak zapis zachowkowy czy darowizna na poczet zachowku nie zawierają w sobie informacji, ze ów zapis bądź darowizna uczyniona jest „na konto” nie tyle zwykłego zachowku, ile tej jego części, którą spadkodawca może swobodnie rozporządzać na rzecz zstępnych.

\section{Organy spółek kapitałowych}

W polskim i hiszpańskim systemie prawnym istnieją odpowiadające sobie typy spółek a tłumaczenie ich nazw nie nastręcza większych trudności. Odkąd ustawą nr 2/2007 z 15 marca 2007 r. ${ }^{12}$ wprowadzono w Hiszpanii typ spółki przeznaczony do prowadzenia określonych rodzajów działalności zawodowej (sociedad profesional), w porządku prawnym tego państwa można odnaleźć wszystkie postacie spółek osobowych i kapitałowych występujących w systemie polskim. Ich zestawienie przedstawiono w poniższej tabeli:

Tab. 1. Typy spółek w prawie polskim i hiszpańskim

\begin{tabular}{|l|l|}
\hline SPÓŁKA POLSKA & SPÓŁKA HISZPAŃSKA \\
\hline spółka jawna & sociedad collectiva \\
\hline spółka partnerska & sociedad professional \\
\hline spółka komandytowa & sociedad comanditaria \\
\hline spółka komandytowo-akcyjna & sociedad comanditaria por acciones \\
\hline spółka z ograniczoną odpowiedzialnością & sociedad de responsabilidad limitada \\
\hline spółka akcyjna & sociedad anónima \\
\hline
\end{tabular}

Przedmiotem poniższej analizy będzie struktura organów w spółkach kapitałowych, tj. w spółce z ograniczoną odpowiedzialnością oraz w spółce akcyjnej.

O ile same odpowiedniki nazw spółek kapitałowych nie budzą wątpliwości, o tyle struktura ich organów jest odmienna. W polskim prawie spółek, w ślad za systemem niemieckim, zdecydowano się na model organizacji wewnętrznej odzwierciedlający podział na organ prowadzący sprawy spółki i reprezentujący ją wobec osób trzecich (zarząd) oraz organ kontrolujący prawidłowość tych czynności (rada nadzorcza). Zarząd może być organem jedno lub wieloosobowym, a jego decyzje przyjmują formę uchwały. Sposób, w jaki reprezentuje spółkę na zewnątrz określa statut lub umowa spółki, zaś w braku takiego postanowienia art. $205 \S 1$ i art. $373 \S 1$ Kodeksu spółek handlowych przewidują reprezentację łączną przez dwóch członków zarządu lub przez jednego członka zarządu wraz z prokurentem ${ }^{13}$. Rada nadzorcza natomiast to zawsze

\footnotetext{
${ }^{11}$ Lacruz Berdejo 2007, 337.

${ }^{12}$ Ley 2/2007, de 15 de marzo, de sociedades profesionales (BOE de 16 de marzo de 2007).

${ }^{13}$ Prokura to niewystępująca w Hiszpanii instytucja prawna przejęta przez system polski z prawa niemieckiego. Prokurent jest szczególnym rodzajem pełnomocnika przedsiębiorcy, umocowanym do reprezentowania go we wszystkich sprawach sądowych i pozasądowych związanych z prowadzeniem przedsiębiorstwa (art. 109 Kodeksu cywilnego) i ujawnianym w rejestrze przedsiębiorców. Termin ten bywa najczęściej tłumaczony na język hiszpański jako apoderado mercantil lub apoderado general, przy czym ten drugi ekwiwalent może
} 
organ kolegialny, podejmujący decyzje w drodze uchwały. Jej ustanowienie nie jest obowiązkowe w spółkach $\mathrm{z}$ ograniczoną odpowiedzialnością o kapitale zakładowym niższym niż 500 tysięcy zł oraz liczącej do 25 wspólników (art. 213 § 2 Kodeksu spółek handlowych). Ponadto wyłącznie w spółkach z ograniczoną odpowiedzialnością można zamiast, lub obok, rady nadzorczej ustanowić komisję rewizyjną, odpowiedzialną za badanie prawidłowości rocznych sprawozdań finansowych oraz sprawozdań z prowadzenia spraw spółki (art. 221 Kodeksu spółek handlowych). W praktyce osoby prawne rzadko decydują się na wprowadzenie tej formy kontroli wewnętrznej. Niemniej jednak wydaje się, że w tłumaczeniu na język hiszpański powinno zachować się formę comisión de revisión, ewentualnie comisión de control.

Hiszpański system natomiast, przewiduje utworzenie tylko jednego organu zarządzającego całością spraw spółki (órgano de administración). Struktura taka jest zbliżona do modelu występującego w prawie państw anglosaskich. Ciało zarządzające może przybierać różne formy organizacyjne. Wybraną formę powinien wskazywać statut spółki. Dokument ten może jednak przyznawać prawo wyboru oraz zmiany formy organizacyjnej zgromadzeniu wspólników (art. 57 ust. 1 ustawy o spółkach z ograniczona odpowiedzialnością, art. 123 ust. 1 ustawy o spółkach akcyjnych). Organ zarządzający moga tworzyć pojedyncze osoby - administradores. Jeżeli do ważnego dokonywania czynności prawnych w imieniu spółki potrzeba działania łącznego członków tego organu, mamy do czynienia $\mathrm{z}$ administradores mancomunados, jeśli zaś każdy z członków umocowany jest do działania samodzielnego, noszą oni miano administradores solidarios. Ciało to może jednak zostać zorganizowane w sposób kolegialny. Wtedy nosi nazwę consejo de administración a jego członkowie, w liczbie co najmniej trzech, określani są terminem consejeros. Dopiero tak utworzone ciało podejmuje decyzje w drodze uchwały. Wybór kolegialnego modelu zarządu pociąga za sobą konieczność określenia którzy jego członkowie mogą reprezentować ten organ na zewnątrz. W tej sytuacji, podobnie jak w przypadku powierzenia prowadzenia spraw spółki pojedynczym osobom, można umocować jednego członka ciała kolegialnego (consejero delegado), kilku z nich do działania łącznego (consejeros delegados mancomunados) lub kilku $\mathrm{z}$ nich do działania samodzielnego (consejeros delegados solidarios). Istnieje również możliwość wyodrębnienia ciała kolegialnego o mniejszym składzie, czyli komisji wykonawczej (comisión ejecutiva).

Oprócz tego w obu systemach występuje organ reprezentujący interesy właścicieli osoby prawnej, czyli zgromadzenie jej wspólników. Podczas gdy w prawie hiszpańskim zarówno zgromadzenie wspólników spółki z ograniczoną odpowiedzialnością, jak i spółki akcyjnej, posiada tę samą nazwę - junta general - polski Kodeks spółek handlowych rozróżnia pomiędzy zgromadzeniem wspólników w spółce z ograniczoną odpowiedzialnością oraz walnym zgromadzeniem w spółce akcyjnej.

W poszukiwaniu najlepszego sposobu przekładania pojęć dotyczących organów spółek kapitałowych warto wziąć pod uwagę rozwiązania zawarte w obowiązujących w obu państwach tekstach prawa wspólnotowego. Bardzo dobrym przykładem jest w tej sytuacji rozporządzenie Rady (WE) nr 2157/2001 z dnia 8 października $2001 \mathrm{w}$ sprawie statutu spółki europejskiej (SE). Celem tego aktu było wprowadzenie jednolitej podstawy

niekiedy prowadzić do konfuzji, jeżeli przedsiębiorca, poza prokurą, udzielił też innego (zwykłego) pełnomocnictwa ogólnego. 
prawnej i zasad tworzenia ponadnarodowego typu spółki, opartego konstrukcyjnie na modelu spółki akcyjnej. Taka unijna osoba prawna podlegać miała takim samym przepisom w każdym państwie członkowskim ${ }^{14}$, jest też uprawniona do przenoszenia siedziby w obrębie Unii bez konieczności przeprowadzenia postępowania likwidacyjnego. Najistotniejszym dla tłumacza jest jednak sposób ukształtowania struktury organizacyjnej spółki europejskiej. Podczas tworzenia spółki założyciele mogą wybrać dowolnie monistyczny albo dualistyczny system organizacyjny, niezależnie od tego, na jakim systemie opiera się krajowy typ spółki. Dlatego też tłumacz rozporządzenia $\mathrm{nr}$ 2157/2001 na język hiszpański musiał wprowadzić do języka prawnego ekwiwalenty organów systemu dualistycznego, a osoba dokonująca przekładu tego samego aktu na język polski odpowiednio systemu monistycznego. Co więcej, analogiczne pojęcia musiał również wprowadzić ustawodawca redagując wspomnianą już ustawę krajową rozszerzającą i uzupełniającą treść rozporządzenia. W samym rozporządzeniu nr 2157/2001 możemy odnaleźć pojęcia generyczne, odnoszące się nie do nazwy określonego organu lecz do spełnianej przez niego funkcji. Polska wersja mówi tu o organie administracyjnym $\mathrm{w}$ modelu monistycznym oraz organie zarzqdzajacym i organie nadzorczym $\mathrm{w}$ odniesieniu do struktury dualistycznej. Hiszpański tekst rozporządzenia zawiera, odpowiednio, terminy órgano de administración oraz órgano de dirección i órgano de control. W obu analizowanych przypadkach ustawodawcy krajowi decydują się na odesłanie do norm wewnętrznych w odniesieniu do modelu obowiązującego dla zwykłych spółek akcyjnych i wprowadzają nowe pojęcia dla organów występujących $w$ modelu dotychczas nieprzyjmowanym $\mathrm{w}$ obrębie własnego systemu prawa. Pojęcia te nie są kopiami określeń zawartych w rozporządzeniu, ale nazwami organów spółki europejskiej zarejestrowanej, odpowiednio, w Hiszpanii lub w Polsce. Ustawodawca hiszpański zdecydował się na terminy dirección i consejo de control a prawodawca polski na radę administrujacq. W nawiązaniu do wersji polskiej, porównując pojęcia użyte przez ustawodawcę krajowego oraz tłumacza tekstu unijnego należy wskazać, że trafniejszy wydaje się dobór przymiotnika administrujący niż administracyjny. Jest to bowiem organ, do którego kompetencji należy szeroko rozumiane administrowanie, czyli inaczej zarządzanie, spółką, nie zaś organ właściwy dla administracji, zwłaszcza, że termin organ administracyjny ma w polskim języku prawnym i prawniczym utarte już znaczenie i odnosi się do jednostki odpowiedzialnej za zadania administracji państwowej, samorządowej lub prywatnej, np. do urzędów lub ministerstw. Rozwiązania nazewnicze przyjęte przez ustawodawców krajowych w celu rozwinięcia rozporządzenia unijnego wydają się być prawidłową alternatywą dla dotychczasowych tłumaczeń określeń tych organów w polskich i hiszpańskich krajowych typach spółek. Wątpliwa wydaje się jednak konieczność wprowadzania określeń nowych, zwłaszcza w przypadkach, kiedy w praktyce obrotu ustaliły się już pewne ekwiwalenty.

\footnotetext{
${ }^{14}$ W rzeczywistości jednak rozporządzenie 2157/2001 przewiduje konieczność wydania uzupełniających je ustaw krajowych, które z kolei odsyłają częściowo do obowiązujących w państwie członkowskim przepisów dotyczących krajowego typu spółki akcyjnej, co powoduje istnienie niejako 27 wariantów jednolitej spółki europejskiej. Niemniej jednak podstawowe zasady tworzenia i organizacji tej osoby prawnej zostały ujednolicone.
} 
Na tle powyższych uwag prawnoporównawczych szczególnie ciekawym wydaje się zagadnienie tłumaczenia na język polski pojęcia administrator. Możliwe wydają się dwa wyjścia $\mathrm{z}$ sytuacji. Jednym $\mathrm{z}$ nich byłoby potraktowanie hiszpańskiego órgano de administración, niezależnie od tego, ilu osobom i w jaki sposób zostają powierzone jego funkcje w konkretnej spółce, jako zarzqdu, a tym samym nazwanie osób wchodzących w jego skład członkami zarzqdu, rezerwując przy tym dla consejeros termin członkowie zarzqdu kolegialnego. Inne rozwiązanie mogłoby polegać na użyciu określenia zarzqdca w odniesieniu do pojedynczych osób, którym powierzono funkcje prowadzenia spraw spółki i reprezentowania jej, zachowując pojęcie członek zarzq̨du jedynie dla osób należących do ciała kolegialnego. W praktyce pojęcia te rzadko występują razem w jednym dokumencie, jednak ujednolicenie używanej przez tłumacza terminologii w tym zakresie wydaje się pożądane.

Kolejną wątpliwość nasuwa przekład na język polski funkcji consejero delegado. Jest to członek zarządu w formie kolegialnej, który został uprawniony do reprezentowania tego ciała wobec osób trzecich (np. organów państwowych, notariusza itp.). Możliwe ekwiwalenty: umocowany członek zarzqdu, upoważniony członek zarzqdu, petnomocny członek zarzadu nie są czytelne dla odbiorcy polskiego nie znającego dokładnie sposobu działania organów hiszpańskich. Najbardziej zrozumiała wydaje się wersja opisowa członek zarzqdu upoważniony do reprezentacji, zastępowana ewentualnie w dłuższym tekście formą upoważniony członek zarzqdu lub analogiczną.

Nie do końca jasnym pozostaje przekład terminów administradores solidarios oraz administradores mancomunados. Wbrew pewnemu podobieństwu określenia te nie odnoszą się do odpowiedzialności zarządców, a do sposobu, w jaki działają reprezentując spółkę (forma de actuación ${ }^{15}$ ). Odpowiedzialność zarządców za zawinione niedopełnienie ciążących na nich obowiązków i niedochowania należytej staranności podczas prowadzenia spraw spółki, niezależnie od modelu organu zarządzającego, który został wybrany w danej spółce, reguluje art. 133 ustawy o spółkach akcyjnych oraz odsyłający do tego przepisu art. 69 ust. 1 ustawy o spółkach z ograniczoną odpowiedzialnością. Odpowiedzialność ta zawsze ma charakter solidarny i obejmuje wszystkie osoby pełniące funkcję zarządcy w dniu upływu terminu, w którym odpowiedni obowiązek powinien zostać wykonany ${ }^{16}$.

Pojęcie solidarności użyte w stosunku do zarządców spółki odnosi się do sposobu, w jaki osoby te składają oświadczenie woli w imieniu spółki. Administradores mancomunados są uprawnieni jedynie do działania łącznego, podczas gdy administradores solidarios mogą działać samodzielnie. Solidarność oznacza tutaj, że działanie podjęte przez któregokolwiek zarządcę jest uważane za działanie całego organu, stanowiącego w tym wypadku zespół samodzielnych osób prowadzących sprawy spółki. Oświadczenie woli jednego, kilku dowolnych lub nawet wszystkich takich zarządców w taki sam sposób wiąże spółkę. W przypadku ustsanowienia administradores mancomunados tylko oświadczenie woli złożone przez wszystkich jest ważne i skuteczne. Kolejny argument przemawiający za tłumaczeniem tych instytucji w sposób podkreślający ich zakres umocowania nawiązuje do systematyki dokumentów, w których pojawiają się najczęściej te określenia. Wskazanie typu, w jaki ma byś sprawowany zarząd pojawia się w statucie

\footnotetext{
${ }^{15}$ Esturillo López 1996, 281.

${ }^{16}$ Rojo, Beltrán 2009, 286.
} 
lub umowie spółki w związku z jej reprezentacją wobec osób trzecich, nie zaś w związku z postanowieniami dotyczącymi odpowiedzialności członków jej organów. Z powyższych powodów autorka wystapienia preferuje tłumaczenie administradores solidarios jako członkowie zarzqdu/zarzadcy działajacy samodzielnie a administradores mancomunados jako członkowie zarzadu/zarzqdcy działajacy wspólnie.

Ostatnim terminem, który bywa przekładany w różny sposób jest rada nadzorcza. Obok najczęściej występującego wariantu consejo de supervisión można spotkać też propozycje consejo de vigilancia oraz consejo de control (przede wszystkim za rozporządzeniem 2157/2001). Trudno znaleźć argumenty natury wyłącznie prawnej, które przemawiałyby na rzecz jednego tylko ekwiwalentu. Wydaje się jednak, że w celu ujednolicenia funkcjonującej $\mathrm{w}$ obrocie terminologii należałoby preferować wariant najczęściej używany, nawiązujący zresztą nie tylko do funkcji, ale i do samej nazwy organu polskiego. Jeżeli w myśl kodeksów dobrych praktyk obowiązujących spółki uczestniczące w publicznym obrocie papierami wartościowymi w obrębie rady nadzorczej zostały powołane komitety wewnętrzne ${ }^{17}$ zgodnie $\mathrm{z}$ obowiązującą w tym zakresie terminologią hiszpańską ich nazwy będą przekładane z użyciem pojęcia comisión ${ }^{18}$.

\section{Podsumowanie}

Struktura systemu prawa hiszpańskiego nie różni się istotnie od struktury polskiego porządku prawnego. Oba omawiane porządki prawne należą do wywodzącego się z prawa rzymskiego oraz praw plemion germańskich systemu prawa kontynentalnego. Tym samym wiele występujących w nich pojęć prawnych znajduje swój bezpośredni ekwiwalent w porządku prawnym drugiego panstwa. Problemem dla tłumacza może być odmienne rozumienie $w$ nauce prawa pojęć określających instytucje spełniające zbliżone funkcje. To odmienne rozumienie odzwierciedla się niekiedy również w składni czy formie gramatycznej poszczególnych wyrażeń. Poszczególne cechy dyskursu danego języka prawnego i prawniczego mogą znajdować uzasadnienie w cechach języka ogólnego, tradycji, ale też w sposobie, w jaki dane pojęcia są rozumiane przez przedstawicieli doktryny określonej gałęzi prawa. Systematyka terminów obcojęzycznych wymaga nie tylko wiedzy specjalistycznej z zakresu językoznawstwa czy nauk prawnych, ale też odpowiedniej znajomości praktycznego i teoretycznego funkcjonowania zestawianych systemów normatywnych oraz dotychczasowej praktyki tłumaczeniowej. Ten ostatni aspekt ma szczególne znaczenie w odniesieniu do tłumaczeń urzędowych aktów prawa międzynarodowego i unijnego.

\footnotetext{
${ }^{17}$ Zalecenia wydane przez Komisję Europejską wskazują tu komitet audytu, komitet wynagrodzeń i komitet nominacji.

${ }^{18}$ Hiszpańskie dokumenty używają pojęć: comisión de auditoría, comisión de remuneraciones oraz comisión de nominaciones.
} 


\section{Bibliografia}

Calvo Caravaca, Alfonso-Luís, Carrascosa González, Javier, 2009. Derecho Internacional Privado, Granada Comares.

Esturillo López, Antonio, 1996. Estudio de la Sociedad de Responsabilidad Limitada, Madrid, Civitas.

Lacruz Berdejo, José Luís, 2007. Elementos de Derecho civil, t. V: Sucesiones, Madrid, Dykinson.

Pazdan, Maksymilian, 2008. Prawo prywatne międzynarodowe, Warszawa, Lexis Nexis.

Rojo, Ángel, Beltrán, Emilio, 2009. La responsabilidad de los administradores de las sociedades mercantiles, Valencia, Tirant lo Blanch.

Sójka-Zielińska, Katarzyna, 2003. Historia prawa, Warszawa, Lexis Nexis. 